\title{
Programmed home visits by nursing professionals to older adults: prevention or treatment? ${ }^{1}$
}

\author{
Caridad Dios-Guerra² \\ Juan Manuel Carmona-Torres ${ }^{3}$ \\ África Ruíz-Gándara ${ }^{4}$ \\ Adoración Muñoz-Alonso ${ }^{5}$ \\ María-Aurora Rodríguez-Borrego ${ }^{6}$
}

\begin{abstract}
Objetivos: conocer la repercusión de la visita domiciliaria de los profesionales en enfermería a personas de 65 años o más, pluripatológicas, en morbimortalidad. Método: estudio retrospectivo caso-control por auditoria de historias clínicas. Muestreo aleatorio. Variables principales morbilidad, mortalidad; descriptivas: visitas de la enfermera, filiación, datos clínicos y socio sanitarios. Análisis por medidas de tendencia central, dispersión, posición, tabulación, frecuencias relativas, absolutas; no paramétricas, contrastes $x 2$; Wilcoxon-Mann-Whitney. Resultados: se estudiaron a 1743 pacientes, de ellos 199 recibieron visita domiciliaria; la edad media de quien recibe visita es de 81,99 años; estos presentan mayor número de patologías de media 3,76; habitan en domicilio particular, si bien en conjunto presentan más institucionalización que los controles; el 50\% no tiene identificado el Cuidador Principal; es mayor el número de visitas de las enfermeras a los pacientes que viven en residencias ( $<<0,001)$. El 50\% de casos no tiene plan de cuidados, con relación significativa $(p<0,001)$. No existen diferencias significativas en tiempo de vida entre los casos y los controles. Conclusión: la visita domiciliaria del profesional en enfermería no repercute en la morbimortalidad; visita a los pacientes cuando ya ha aparecido el problema de salud, no hay datos de prevención.
\end{abstract}

Descriptors: Home Visit; Disease; Nurse; Morbidity; Mortality.

\footnotetext{
1 Paper extracted from doctoral dissertation "Estudio del efecto de la visita domiciliaria programada y protocolizada de la enfermera de Atención Primaria en la morbilidad en pacientes de 65 o más años pluripatológicos", presented to Universidad de Córdoba, Córdoba, Andalucía, Spain. 2 MSc, Associate Professor, Departamento de Enfermería, Facultad de Medicina y Enfermería, Universidad de Córdoba, Córdoba, Andalucía, Spain.

3 MSc, RN, Hospital Infanta Luisa, Sevilla, Andalucía, Spain.

${ }^{4} \mathrm{PhD}$, RN, UGC Santa Rosa, Servicio Andaluz de Salud, Córdoba, Andalucía, Spain.

${ }^{5}$ MSc, Assistant Professor, Departamento de Estadística, Universidad de Córdoba, Córdoba, Andalucía, Spain.

${ }^{6}$ PhD, Full Professor, Departamento de Enfermería, Universidad de Córdoba, Córdoba, Andalucía, Spain.
}

\section{Corresponding Author:}

Caridad Dios-Guerra

Universidad de Córdoba. Facultad de Medicina y Enfermería

Departamento de Enfermería

14004, Córdoba, Andalucía, España

E-mail: cdios@uco.es
Copyright $\odot 2015$ Revista Latino-Americana de Enfermagem

This is an Open Access article distributed under the terms of the Creative Commons Attribution Non-Commercial License (CC BY-NC).

This license lets others distribute, remix, tweak, and build upon your work non-commercially, and although their new works must also acknowledge you and be non-commercial, they don't have to license their derivative works on the same terms. 


\section{Introduction}

The population in the 65 and over age group is increasing significantly and of these, the number of very elderly (80 and over) is growing, as reflected in the recently published Global Ageing Index, in-depth report, $2014^{(1)}$. In Spain, in particular, $16 \%$ of the population is aged over 65 and the very elderly form almost $25 \%$ of all older adults; if current mortality rates continue, by the middle of this century this latter group will account for around $30 \%$ of all older adults - those aged over $65^{(2)}$. Among the problems resulting from the ageing population, the difficulties the health care services face in dealing with increased demand from the needs of the ageing population stand out, difficulties which affect not only increased care costs but also organizational capacity at different levels of the care system. Primary and/or Community Health Care Teams, and especially nursing professionals who form part of them, are one of the strengths of the system for carrying out interventions to meet the above mentioned needs, especially those of dependent citizens in health situations that lead to fragility, living in their own homes; as well as the needs of the families who care for them, who need specialists to help them plan and administer care ${ }^{(3-4)}$. A common epidemiological profile among those who require home care is: multi-pathological (more than two chronic illnesses), polymedicated, fragility or a high degree of invalidity, dependent on formal or informal carers, requiring health care which, especially because dealing with individuals of an advanced age or with functional and/or cognitive limitations, is provided at home or in institutions by Primary and/or Community nursing staff ${ }^{(5-6)}$. A systematic review ${ }^{(7)}$ of the effectiveness of different care models in patients with heart failure concluded that re-hospitalization is much lower for this population when there is homecare which is well planned and with specific interventions both at home and on an outpatient basis by nurses, and place emphasis on a new role for nursing professionals, focusing on home and multi-disciplinary care, structured telephone monitoring, help, carer support, families and guaranteed continuity of care through specially created clinical pathways. As for emergency service use by the older adult population (8-9) the data vary according to different environments, cultures and/or causes, although the figure is considerable, around $30 \%$. Faced with the complexity and variety of facets to the situation, the research team questioned the work of nursing professionals in the community and its impact on citizens' health, envisaging a study with the aim of discovering the impact of planned home visits by health care professionals working in Primary/Community Care services to multi-pathological individuals aged 65 and over, in the own home or in nursing homes (in the case of those who were institutionalized), on the morbimortality of the population cared for.

\section{Method}

This was a retrospective case-control study. The subjects were patients aged 65 and over who used the Andalusian Health Care System (SAS), belonging to the Córdoba-Guadalquivir Health Care district (formed of 13 urban health care centers, 6 on the outskirts and 24 rural), serving a total of 76,452 patients. Inclusion criteria for both groups were: being aged 65 or over and diagnosed with 2 or more chronic diseases from $1^{\text {st }}$ January 2013, individuals belonging to the health care district mentioned and subsidized to receive home care (in the patient's home or in a nursing home) from a nursing professional from their local health care center. The cases group of patients were those who received and average of 6 or more programmed visits a year ${ }^{(5)}$ (based on the review study Programmed Nursing home visits to over 65s -Visita domiciliaria programada de enfermería a persona mayores de 65 años, published by the Ministry of Health and Consumo Español in 2002) by nursing professionals. The control group was formed of those who received home care from the professional when the patient requested it ( 5 or fewer visit per year). In order to calculate the sample size, the main result variable was used as a reference: percentage of patients deceased when followed up after 18 months (mortality rate); based on the results obtained in a clinical trial concerning programmed home visits with fragile older adults ${ }^{(10)}$. The EPIDAT 3.1 program was used (Calculating sample size to estimate relative risk) with the following assumptions: exposed (intervention to be tested) at $14 \%$ mortality risk; non exposed (normal intervention) at $18 \%$ mortality risk; expected Relative Risk: 0.778 . Control Group to Case Group Ration 1:1. Level of confidence: $95 \%$, and for relative precision of $80 \%$ the resulting sample size was 826 subjects per group, with an estimated non-response rate of $10 \%$. N final= $\mathrm{N}$ previous $[1 /(1-\mathrm{R})]=826[1 /(1-0.10)]=918$ subjects $/$ group. Total sample: 1,836. Patients aged over 64 in areas corresponding to the Córdoba-Guadalquivir health district number 76,452. In the Córdoba (capital) area: $53,898$ (70.50\% de 76,452$) 1,294$. In the Guadalquivir 
area (province): 22,554 (29.50\% of 76,452) 542 older adults. Later, there were two follow ups of random patients who were part of the sample. The sources of the data were the databases from the Health Districts in question and the Electronic Medical History (DIRAYA), it was from the latter that the usual clinimetric instruments for the activities of the nursing professional were found: questionnaires evaluating function (Barthel)(11) and (Lawton and Brody)(12); cognition (Pfeiffer's Test)(13); risk of pressure sores (Norton) ${ }^{(14)}$, risk of falls (Risk of multiple falls) ${ }^{(15)}$ and the questionnaire evaluating Basic Needs according to Virginia Henderson, the model of used in the District studied. The main variables were morbidity and mortality; and the descriptive variables were: number of home visits by the nursing professional and patients' socio-demographic, medical and socio-health case data. Data were collected from auditing the medical histories of patients selected through the above mentioned sampling procedure; the study took place between May and September 2013; the information collected from the medical histories was limited to information from the year preceding the audit. The SPSS 15 statistics package was used to analyze the data and descriptive analysis was conducted: measuring central trends, dispersion and position of the quantitative variables in question; the data were tabulated and relative and absolute frequencies were calculated for the qualitative data. For statistical inference analysis, the following techniques were used: techniques in the parametrics differed for cases and controls and proportions were compared using $\mathrm{x} 2$ contrasts. As for the quantitative variables, means were compared using Wilcoxon-Mann-Whitne contrasts for all variables deemed relevant. Analyses of the result variables (mortality and morbidity) were crossed with socio-demographic and other independent variables or with prognostics of interest, gathered in the study; where necessary, Pearson's c2 test and Fisher's exact test, together with contingency tables, were used for those where joint relative frequencies had been calculated for each of the types crossed. All of the contrasts used were bilateral, with a $95 \%$ confidence level. This study was approved by the Research Ethics Committee of the Province of Córdoba and at all times respected Law 15/1999, of 13 December concerning Protecting Data of a Personal Nature.

\section{Results}

The results will be organized and explained in blocks, the first of which is based on the sample $(1,743)$, comparing patients receiving home care from nursing professionals and those who are not (199-1544). A second block, composed of patients who received home visits from a nursing professional 197 cases and 1564 controls, noting differences. Of the 1,836 patients in the sample, 93 were excluded as there were no records in the medical history for the period in question, leaving 1743 patients as the final sample $(\mathrm{N})$; of these, 1,546 did not receive home visits from a nursing professional, and 199 did. Of the total $\left(N_{1}, 743\right), 1,050$ were female $(60.2 \%)$ and 693 male (39.8\%). The mean age of the individuals visited by nursing staff was 81.99 (SE 0.539) compared with 74.87 (SE 0.183) for those who did not, with 82.82 years old (SE 0.611) for the women and 79.91 (SE 1.06) for the men. Regarding age, that of the cases exceeded that of the controls, with a mean 82.89 years old, compared with 74.76 (SE 0.541-0.179 respectively). Differences were observed between men and women, including in home care, with women being older (82.82). Table 1 shows morbidity from the most prevalent chronic diseases. The mean number of pathologies was 2.92 (SD 1.449) with the highest percentage for individuals with 3 or more pathologies $(27.8 \%)$, followed by 2 $(24.8 \%)$ and $4(18.5 \%)$. On average, women had more pathologies than men; 3.01 and 2.78 respectively (SE $0.0045)$. Patients who received visits from the Nurse were those with the highest number of pathologies, with a mean 3.76 (SE 0.107), compared with 2.81 of those who did not receive this service.

As for medicine use, around $90.5 \%$ of the patients were on medication (55.4\% of women and $35.2 \%$ of men). On average, the women took more medicine than the men; 6.88 (SE 0.119); and when comparing pharmaceutical use between patients who received home visits and those who did not, mean consumption was higher in the former 8.42 (SE 0.269). The cases used more pharmaceuticals (in number) than the controls ( $p<$ 0.001 ) with a mean 8.79 compared with 6.31 (SD 3.653.54 respectively). Of the 1,743 individuals studied, 199 received visits from the nurse, corresponding to $11.4 \%$ of the total ( $8.1 \%$ women and $3.3 \%$ men). As for socio-sanitary resources, in general, in this study, it is below the number registered allowing us to infer lack of utilization; except for help with dependence which was requested by 45.75 of those patients who received home visits; compared with the data for the total sample (see Table 2).

Regarding habitual residence (private residence or nursing home), $96.6 \%$ of patients lived in their own home (according to sex, $57.8 \%$ of the women and 
$38.7 \%$ of the men) and $3.2 \%$ in a nursing home $(2.2 \%$ women); the mean age was 82 (SD 7.4) of those living in their own home, compared with 82.121 for those who lived in a nursing home (SD 8.91); presence of the Main Carer (MC) in the home was not identified in $52.8 \%$ of patients who received home visits, see Table 3, with the mean age higher in those patients who had identified the main carer $(p<0.001)$.

As for the relation between the number of visits from nursing staff and Main carer, the data indicate significant differences ( $p<0.001)$, with patient visits more common when the Main carer was identified than when not. The mean number of visits from the nurse was 2.44 (SD 12.479) for the patients who lived in their own home and 4.75 (SD 5.148) for those who lived in nursing homes for the elderly in rural areas, with 2.95 (SD 19.67) and 6.08 (SD 11.28) in the urban area. In both the rural and urban zone, the number of nursing visits to patients in nursing homes was higher than those who lived in their own home ( $p<0.001)$. As for specific assessment documents (clinimetric instruments), 70\% did not have Barthel, $85.4 \%$ did not have the Pfeiffer test, $95.6 \%$ did not have Salwton, $93.1 \%$ did not have
Norton, $94.6 \%$ did not have the test for falls and have $73.8 \%$ had not recorded assessments using the Virginia Henderson care model; some $81.7 \%$ had not recorded the Nursing Care plan. Of all the patients ( $N$ 1,743) $11 \%$ had their needs evaluated and a Care Plan. When these variables were analyzed in only patients who had received a home visit from a nurse (N199), the mean number of questionnaires administered was 2.12 (SD 1.39), the Barthel questionnaire was the most frequent, with $75.4 \%$, followed by the Pfeiffer, with $44.2 \%$ and that of Norton with $33.2 \%$. Some $40.7 \%$ of patients had an evaluation and care plan recorded in their medical history, 20.6\% had neither an evaluation nor a Care Plan; $33.7 \%$ had an evaluation but no Care Plan; and $5.0 \%$ had no evaluation but had a Care Plan. As for the case and control groups, $45.7 \%$ of the cases had care plans, as did $8.6 \%$ controls; there was a significant relationship between having a plan or not and having home care visits $(p<0.001)$. There were also differences concerning the number of diseases, use of resources and questionnaires, with the case group that which had the highest values for these variables, compared with the control group. (Table 4).

Table 1 - Chronic diseases in the total sample $(n=1,743)$. Córdoba, CAA, Spain, 2014

\begin{tabular}{lccccc}
\hline \multicolumn{1}{c}{ Pathology } & N patients & Percentage & Men $\%$ & Women \% & Differentiated by sex \\
\hline Cardiovascular & 1392 & 79.9 & 31.0 & 48.9 & No \\
Respiratory & 333 & 19.1 & 10.0 & 9.1 & Yes(M) \\
Musculoskeletal & 894 & 48.7 & 12.6 & 36.1 & Yes(W) \\
Digestive & 379 & 21.7 & 7.9 & 13.9 & No \\
Metabolic & 607 & 34.8 & 13.1 & 21.7 & No \\
Urinary & 391 & 22.4 & 10.8 & 11.6 & Yes(M) \\
Neurological & 163 & 9.4 & 3.8 & 11.5 & No \\
Mental & 260 & 14.9 & 3.4 & 4.5 & Yes(W) \\
Tumor & 194 & 11.1 & 11.4 & & Yes(M) \\
Other & 523 & 30.0 & & & No \\
\hline
\end{tabular}

Table 2 - Requesting dependency support according to sex and environment for the whole sample $(n=1,743)$. Córdoba, CAA, Spain, 2014

\begin{tabular}{|c|c|c|c|c|c|c|}
\hline \multirow{2}{*}{\multicolumn{4}{|c|}{ Location }} & \multicolumn{2}{|c|}{ Sex } & \multirow{3}{*}{$\begin{array}{c}\text { Total } \\
459\end{array}$} \\
\hline & & & & \multirow{2}{*}{$\begin{array}{c}\text { Male } \\
212\end{array}$} & \multirow{2}{*}{$\begin{array}{c}\text { Female } \\
247\end{array}$} & \\
\hline Rural & Requested & No & Number & & & \\
\hline & & & $\%$ of total & $41.5 \%$ & $48.3 \%$ & $89.8 \%$ \\
\hline & & Yes & Number & 12 & 40 & 52 \\
\hline & & & $\%$ of total & $2.3 \%$ & $7.8 \%$ & $10.2 \%$ \\
\hline & Total & & Number & 224 & 287 & 511 \\
\hline & & & $\%$ of total & $43.8 \%$ & $56.2 \%$ & $100 . \%$ \\
\hline \multirow[t]{6}{*}{ Urban } & Solicitud prestación & No & Number & 418 & 618 & 1036 \\
\hline & & & $\%$ of total & $33.9 \%$ & $50.2 \%$ & $84.1 \%$ \\
\hline & & Yes & Number & 51 & 145 & 196 \\
\hline & & & $\%$ of total & $4.1 \%$ & $11.8 \%$ & $15.9 \%$ \\
\hline & Total & & Number & 469 & 763 & 1232 \\
\hline & & & $\%$ of total & $38.1 \%$ & $61.9 \%$ & $100.0 \%$ \\
\hline
\end{tabular}


Table 3 - Main Carer Identified -Home Visit -Sex $(n=1,743)$. Córdoba, CAA, Spain, 2014

\begin{tabular}{|c|c|c|c|c|c|c|}
\hline \multirow{2}{*}{$\begin{array}{c}\text { Home } \\
\text { Visit }\end{array}$} & & & & \multicolumn{2}{|c|}{ Sex } & \multirow{2}{*}{ Total } \\
\hline & & & & Males & Women & \\
\hline \multirow[t]{6}{*}{ No } & ${ }^{*} \mathrm{MC}$ identified & Not identified /No carer & Number & 610 & 806 & 1416 \\
\hline & & & $\%$ of total & $39.5 \%$ & $52.2 \%$ & $91.7 \%$ \\
\hline & & Identified & Number & 26 & 102 & 128 \\
\hline & & & $\%$ of total & $1.7 \%$ & $6.6 \%$ & $8.3 \%$ \\
\hline & Total & & Number & 636 & 908 & 1544 \\
\hline & & & $\%$ of total & $41.2 \%$ & $58.8 \%$ & $100.0 \%$ \\
\hline \multirow[t]{6}{*}{$\mathrm{Si}$} & ${ }^{*} \mathrm{MC}$ identified & Not identified /No carer & Number & 31 & 74 & 105 \\
\hline & & & $\%$ of total & $15.6 \%$ & $37.2 \%$ & $52.8 \%$ \\
\hline & & Identified & Number & 26 & 68 & 94 \\
\hline & & & $\%$ of total & $13.1 \%$ & $34.2 \%$ & $47.2 \%$ \\
\hline & Total & & Number & 57 & 142 & 199 \\
\hline & & & $\%$ of total & $28.6 \%$ & $71.4 \%$ & $100.0 \%$ \\
\hline
\end{tabular}

*Main carer

Table 4 - Pathology, socio-health resources and home visits by a Nurse for cases and controls $(n=1,743)$. Córdoba, CAA, Spain, 2014

\begin{tabular}{|c|c|c|c|c|}
\hline \multicolumn{3}{|c|}{ Group } & \multirow{2}{*}{$\begin{array}{c}\text { Statistic } \\
2.80\end{array}$} & \multirow{2}{*}{$\frac{\text { Standard error. }}{.036}$} \\
\hline \multirow{4}{*}{ Pathologies } & \multirow{2}{*}{ Controls } & Mean & & \\
\hline & & stand. dev & 1.408 & \\
\hline & \multirow{2}{*}{ Cases } & Mean & 3.87 & .101 \\
\hline & & stand. dev. & 1.418 & \\
\hline \multirow{4}{*}{ Resources } & \multirow{2}{*}{ Controls } & Mean & .06 & .008 \\
\hline & & stand. dev & .317 & \\
\hline & \multirow{2}{*}{ Cases } & Mean & .48 & .053 \\
\hline & & stand. dev & .746 & \\
\hline \multirow{4}{*}{ Questionnaires } & \multirow{2}{*}{ Controls } & Mean & .50 & .024 \\
\hline & & stand. dev & .960 & \\
\hline & \multirow{2}{*}{ Cases } & Mean & 2.32 & .098 \\
\hline & & stand. dev & 1.380 & \\
\hline \multirow{4}{*}{ Nursing visits } & \multirow{2}{*}{ Controls } & Mean & 2.06 & .078 \\
\hline & & stand. dev & 3.053 & \\
\hline & \multirow{2}{*}{ Cases } & Mean & 1.93 & .237 \\
\hline & & stand. dev & 3.325 & \\
\hline
\end{tabular}

On the other hand, the number of patients for whom the beginning of the visits and date of death were collected was 32, of these, 17 had had home visits; the mean number of days was 724 in those who had visits and 586.4 in those who did not (DD 451 - 652, 57 respectively); there were no statistically significant differences regarding life span between cases and controls. The Odds Ratio for pathologies (yes/no) / cases and controls was 6.5254 [CI95\% $=(2.8642-$ 14.8664)], indicating a higher probability of falling ill for the cases compared to the controls.

\section{Discussion}

Before reading this section, it should be noted that the study has certain limitations derived from gaps in the records (missing data), information bias given the heterogeneity of professionals who made the records, and differences in work procedures in the health centers studied. Although the Home Visit Program (HVP) is included in the range of Primary Health Care services provided by the Ministry (16) and is directed at individuals who fall into the protocols of immobile, terminally ill patients, hospital discharge with ongoing care, individuals with debilitating illness, the elderly with chronic illness and others, as mentioned above, this study includes those aged 65 and over with or without programmed home visits; which means that we must first highlight the noteworthy fact of the low coverage of the; the percentage of the elderly who received home visits from nursing staff $(11.4 \%)$ is lower than the estimated prevalence for this service (15\% of those aged 65 and over) ${ }^{(16)}$. As for sex, the majority of those who received home care were women, as seen in other studies with 
similar characteristics ${ }^{(17)}$. According to the EDAP (Survey on Disabilities, Personal Autonomy and Situations of Dependency - Encuesta sobre Discapacidades, Autonomía Personal y Situaciones de Dependencia)(18), in 2008, in Spain (excluding those living in institutions) there were 2,227,086 individuals aged 65 and over with at least one disability and $66 \%$ of those were women. As for residence, the vast majority lived in their own home and a smaller percentage personas in nursing homes or institutions, coinciding with the data from the IMSERSO Observatory of the Elderly(19). Regarding family member carers, only half of patients identified one, although in this study these important individuals are not classified by sex nor by relationship to the dependent; in the bibliography consulted, in the majority of cases they were women, either children or spouses ${ }^{(20)}$. As for the clinical-epidemiological characteristics, the presence of chronic diseases is noticeable, with a mean of around 4; from a total of 9 medical diagnoses collected, cardiovascular and skeletomuscular and metabolic processes are the most prevalent; this is in line with other studies, including clinical trials conducted with hypertensive patients in Canada ${ }^{(21)}$ which show that $89 \%$ to $100 \%$ have multiple chronic diseases, with a mean varying between 5 and 12. As for pharmacological use, patients living in their own homes often polymedicate, with mean consumption above eight, similar to findings in other studies(22); this poses a risk to patient safety through forgetting to take medicine, or taking it twice, mistakes in understanding the prescription, interactions or adverse effects ${ }^{(23)}$. Concerning the use patients living in their own homes make of autonomy and dependence support material and services, low coverage stands out, although one must take into account the limitations of this study, as it deals with information collected from medical records and it may be that these data are missing from the records. The most commonly used material were walking frames and home help the least, an aspect which is not in line with the literature(24), however, in both cases women are the ones who made most use of them. As for evaluating nursing activities, the audit was inconclusive, due to the heterogeneity of activities and the ways in which they were recorded. It is worth noting that the most commonly registered activities were diagnostic and treatment procedures (taking blood samples, bandaging, injections, taking blood pressure, blood sugar etc.). A recently published study $^{(25)}$ refers to the Community Nurse as the health and social care coordinator for those who are fragile or of an advanced age; data which contrast with those found in this study, in which the low level of use of clinimetric instruments was surprising, as these are essential in drawing up care plans and deciding what the most appropriate interventions are for each case. The most commonly used questionnaires are the Barthel and the Pfeiffer, which may be explained as these questionnaires are used to draw up the Health Conditions Report used to request dependency support, implying that they are used by the professionals in order for the service user to request support rather than for clinical ends. When care characteristics are analyzed, those who received more visits from the nurse are those who were institutionalized, mainly in urban areas, followed by those in institutions in rural areas, a contradictory aspect, as those who are in an institution are those patients who have more support; however, the low number of visits coincides with other studies including the SESPAS (Spanish Society of Public Health and Sanitary Administration - Sociedad Española de Salud Pública y Administración Sanitaria) Report, 2012(26), which insists on increasing the number and the quality of home visits, and that their effectiveness depends on the regularity with which the patient is monitored and on the stability of the programs. The results of this study show that the situation and effects of the home visit have not improved compared with the past ${ }^{(5)}$ and that the coverage of the Home Visit Programs needs to be increased, with more intense monitoring and protocols which include a comprehensive evaluation of the elderly individual, directed at monitoring the health situation, following up care, carrying out preventative measures concerning the safety and quality of life of the patient in their last years; an intervention for which the effects can be measured ${ }^{(27)}$. When planning this study, 4 groups were defined: without home visit and with home visit in the total sample and controls (6 or more visits) and cases (5 or fewer visits). Of the four groups, nursing interventions did not appear to make differences in health care results; the Odds Ratio obtained, the probability of falling ill, allowed us to infer that home visits do not act as a protective factor and that home visits are used when the onset of the pathologies has already occurred. On the other hand, it appears that there may be bias or an involuntary discrimination by sex in the nurses visits, affecting older women, as the data indicate that the oldest individuals are women, they live in their own home, in the home they receive fewer visits and there are a significant number who do not receive any visits and have not identified a Main Carer. 


\section{Conclusion}

There was a low frequency of home visits by nursing professionals and the characteristics of completing specific evaluation documents and care planning did not allow the repercussion of nursing activity on the morbi-mortality of those cared for to be measured; the data suggest that they intervene when the health problem has already appeared, and that evaluation is a mechanical task not followed up by planning, which means health results cannot be measured for this. It may seem that demand, usually for drug treatment, justifies intervention and therefore there is an absence of prevention. This leads to the proposal for a line of research aimed at rigorous care for older adults and perform early functional assessment for multi-factorial intervention in prevention.

\section{References}

1. Zaidi A. Indice Global del envejecimiento 2014. Informe en profundidad. HelpAge International. [acesso 8 dez 2014]. Disponível em: www.globalagewatch.org

2. Calisapié Lopesino $P$, Balbantin López-Ceron A, Porras Muñoz M, Matero Echano Gorria A. Envejecimiento Activo. Libro blanco. Madrid: Ministerio de Sanidad Política Social e Igualdad. IMSERSO; 2011. [acesso 13 dez 2014]. Disponível em: http://www.imserso.es/ imserso_01/envejecimiento_activo/libro_blanco/index. ht

3. Arribas Cacha A, Gasco González S, Hernández Pascual M, Muñoz Borreda E. Coordinadores. Plan de Mejora de Atención Primaria de la Comunidad de Madrid 2006-2009. Madrid. Servicio Madrileño de Salud, Dirección General de Atención Primaria; 2009. [acesso 13 dez 2014]. Disponível em: http://www.madrid.org/ cs/Satellite?blobcol=urldata\&blobheader=application $\%$ 2Fpdf\&blobheadername1 = Contentdisposition\&blobhea dername 2 = cadena\&blobheadervalue $1=$ filename $\% 3 \mathrm{DPa}$ pel+Enfermer\%C3\%ADa+OK.pdf\&blobheadervalue2=la nguage\%3Des\%26site\%3DPortalSalud\&blobkey=id\&bl obtable $=$ MungoBlobs\&blobwhere $=1220445005584 \& s s b$ inary $=$ true

4. Malvárez S. El reto de Cuidar en un mundo globalizado. Texto Contexto Enferm. 2007;16(3):520-30

5. Fuentelsaz Gallego C, De Frutos Sánchez D, Moreno Casbas T, Comet Cortes P, Martín Arribas MC. Visita Domiciliaria Programada de Enfermería a Personas Mayores de 65 años. Madrid: Ministerio de Sanidad y Consumo. Instituto de Salud Carlos III; 2002. [acesso
13 dez 2014] Disponível em: http://bvs.isciii.es/mono/ pdf/INVESTEN_02.pdf

6. Del-Pino-Casado R, Millán-Cobo MD, Palomino-Moral PA, Frias-Osuna A. Cultural correlates of burden in Primary caregivers of older relatives: a cross-sectional study. Journal of Nursing Scholarship. 2014; 46 (3): 176-86

7. Morales Asensio JM. Efectividad de los modelos alternativos de atención para pacientes con insuficiencia cardiaca: revisión sistemática. Rev Cal Asist. 2006;21:51-60.

8. Badiel M, Cepeda MC, Ordoñez C, Pino LF, Loaiza $\mathrm{JH}$, Aboutanos M. Trauma en mayores de 65 años. Experiencia en 2 hospitales Universitarios en Cali. Panam J Trauma,Crit Care Emergency. 2013;2(1):215.

9. Alcock M, Chilvers C. Emergency surgery in the elderly: a retrospective observational study. Anaesth Intensive Care. 2012;40:90-4.

10. Bouman A, van Rossum E, Ambergen T, Kempen $G$, Knipschild P. Effects of a home visiting programme for older people with poor health status: a randomised clinical trial in the Netherlands. J Am Geriatr Soc. 2008;56(3):397-404.

11. Mahoney F L, Barthel DW. Functional evaluation: the Barthel Index. Md Med J. 1965;14:61-5.

12. Lawton MP, Brody EM. Assessment of older people: self-maintaining and instrumental activities daily living. Gerontologist. 1969;9(3):179-86.

13. Martinez de la Iglesia J, Duenas Herrero R, Onis Vilches MC, Aguado Taberne C, Albert Colomer C, Luque Luque R. Adaptación y validación al castellano del cuestionario de Pfeiffer (SPMSQ) para detectar la existencia de deterioro cognitivo en personas mayores de 65 años. Med Clin (Barc). 2001;117(4):129-34.

14. Norton D. Calculating the risk: reflections on the Norton Scale. Decubitus 1989; 2:10.

15. Tromp AM, Pluijm SM, Smit JH, Deeg DJ, Bouter LM, Lips P. Fall-risk screening test: a prospective study on predictors for falls in community-dwelling elders. J Clin Epidemiol. 2001;54(8):837- 44.

16. Ichaso MS. Coordinación. Cartera de Servicios de Atención Primaria. Madrid: Ministerio de Sanidad y Política Social; 2010. [acesso $13 \mathrm{dez} 2014$ ]. Disponível em: https://www.msssi.gob.es/estadEstudios/estadisticas/ docs/siap/Cartera_de_Servicios_de_Atencion_ Primaria_2010.pdf

17. Abellán A, Esparza C, Castejón $\mathrm{P}$, Pérez J. Epidemiología de la discapacidad y la dependencia de la vejez en España. Gac Sanit. 2011;25(S):5-11. 
18. Instituto Nacional de Estadística. Encuesta sobre discapacidades. Tabulaciones web (1999 y 2008). [acesso 24 jul 2014]. Disponível em: http://www.ine. es/inebmenu/mnu salud.htm

19. Díaz Martín R. Coordinadora. Las personas mayores en España. Informe 2008/Tomo I. Madrid: Ministerio de Sanidad y Política Social. IMSERSO; 2009. [acesso 13 dez 2014] Disponível em: http://www.imserso.es/ InterPresent1/groups/imserso/documents/binario/ infppmm2008.pdf

20. Masanet E, La Parra D. Relación entre el número de horas del cuidado informal y el estado de salud mental de las personas cuidadoras. Rev Esp Salud Pública. 2011;85: 257-66.

21. Fortin M, Dionne J, Pinho G, Gignac J, Almirall J, Lapointe L. Randomized controlled trials: do they have external validity for patients with multiple comorbidities?. Ann Fam Med. 2006;4(2):104-8.

22. Molina López T, Caraballo Camacho MO, Palma Morgado D, López Rubio S, Domínguez Camacho JC, Morales Serna JC. Prevalencia de polimedicación y riesgo vascular en la población mayor de 65 años. Aten Primaria. 2012;44(4):216-22.

23. Budnitz DS, Lovergrove MC, Shehab N, Rchards CL. Emergency hospitalizations for adverse drug events in older americans. N Engl J Med. 2011;136:2002-12.

24. Del Pozo Rubio R, Escribano Sotos F, Moya Martínez P. El papel del apoyo informal en las prestaciones del Plan Individualizado de Atención: una elección condicionada para las personas dependientes. Gac Sanit. 2011;25(s):93-9.

25. Steve F. Community nursing offers an increasing range of career paths. Nurs Times. $2014 ; 110(46)$ :S2S3.

26. Corrales Nevado D, Alonso Barrado A, Rodríguez Lozano MA. Continuidad de Cuidados, innovación y redefinición de papeles profesionales en la atención a pacientes crónicos y terminales. Informe SESPAS 2012. Gac Sanit. 2012;26(S):63-8.

27. McHugh GA, Horne M, Chalmers KI, Luker KA. Specialist Community Nurses: A Critical Analysis of Their Role in the Management of Long-Term Conditions. Int J Environ Res Public Health. 2009 Oct;6(10):2550-67. 